INOBIS: Jurnal Inovasi Bisnis dan Manajemen Indonesia

Volume 1, Nomor 3, Juni 2018

Elfira Maya Adiba; Dewi Ayu Wulandari

\title{
Pengaruh Halal Knowledge, Islamic Religiosity, dan Attitude terhadap Behavior Konsumen Muslim Generasi Y Pengguna Kosmetik Halal di Surabaya
}

\author{
Elfira Maya Adiba* \\ Dewi Ayu Wulandari* \\ *STIE Perbanas Surabaya
}

\begin{abstract}
Abstrak
Pasar halal menjadi sektor pertumbuhan ekonomi baru dalam dunia global. Pasar halal tidak hanya pada industri keuangan dan makanan, tetapi juga pada industri kosmetik. Penelitian ini bertujuan untuk mengetahui pengaruh variabel halal knowledge, Islamic religiosity, dan attitude terhadap perilaku pembelian aktual atau behavior konsumen generasi $\mathrm{Y}$ pada pembelian kosmetik halal. Penelitian tentang perilaku konsumen muslim generasi Y dalam pembelian kosmetik halal di Indonesia masih terbatas, sehingga hal ini menarik dilakukan penelitian mengingat generasi $\mathrm{Y}$ adalah generasi yang unik dan berbeda dengan generasi sebelumnya. Teknik analisis data pada penelitian ini adalah multiple regression analysis. Hasil dari penelitian ini yaitu halal knowledge, Islamic religiosity, dan attitude secara parsial berpengaruh positif dan signifikan terhadap behavior konsumen muslim genrasi Y pengguna kosmetik halal di Surabaya. Variabel halal knowledge dan Islamic religiosity secara parsial tidak berpengaruh terhadap behavior konsumen, sedangkan attitude secara parsial berpengaruh positif dan signifikan terhadap behavior konsumen muslim generasi $\mathrm{Y}$ pengguna kosmetik halal di Surabaya.
\end{abstract}

Kata Kunci: halal knowledge, Islamic religiosity, attitude, consumer behavior, halal cosmetic

\section{Pendahuluan}

Pasar halal menjadi sektor pertumbuhan ekonomi baru dalam dunia global. Kehadiran pasar halal ini menjanjikan dan paling cepat tumbuh di Asia, Timur Tengah, Eropa, dan Amerika (Elasrag 2016). Industri halal secara global tidak hanya seputar makanan, melainkan meliputi juga industri farmasi, kosmetik, produk kesehatan, serta komponen sektor jasa seperti logistik, pemasaran, media cetak dan elektronik, kemasan, dan branding (Elasrag 2016). Perubahan tingkah laku konsumen muslim dalam beberapa tahun terakhir dikarenakan peningkatan jumlah penduduk muslim di dunia dan meningkatnya kesadaran para pemuda muslim terhadap produk halal (Swidi et al. 2010).

Kosmetik saat ini menjadi barang yang "harus dimiliki" (must have item) dimana tidak terbatas pada wanita yang menggunakan, tetapi juga bagi sebagian pria (Swidi et al. 2010). Konsumen muslim pada tahun 2012 menghabiskan 26 Milyar (dolar) untuk konsumsi kosmetik dan pengeluaran ini diperkirakan tumbuh hingga 39 Milyar (dolar) pada tahun 2018 (State of the Global Islamic Economy Report, 2013), oleh karena itu pasar kosmetik halal secara global akan berkembang untuk memenuhi kebutuhan konsumen muslim.

Kosmetik halal berbeda dengan produk kosmetik pada umumnya karena kosmetik halal tidak mengandung bahan yang mengandung babi (beserta turunannya) dan tidak mengandung alkohol. Kosmetik halal dalam hal produksi, penyimpanan, pengemasan, dan pendistribusian 
INOBIS: Jurnal Inovasi Bisnis dan Manajemen Indonesia

Volume 1, Nomor 3, Juni 2018

Elfira Maya Adiba; Dewi Ayu Wulandari

juga harus sesuai dengan ajaran Islam. Produk kosmetik halal diakui sebagai produk yang bersih, aman, dan berkualitas tinggi (Mohezar et al. 2016). Perusahaan yang menggunakan halal sebagai branding, maka perusahaan mempunyai tanggung jawab dalam hal pengawasan ketat karena produk halal rawan terkontaminasi oleh zat tidak halal. Masalah etika dalam produksi kosmetik halal serta manajemen perusahaan juga menjadi sorotan konsumen. Pemasar memerlukan strategi yang tepat untuk menjadikan kosmetik berlabel halal ini dapat diterima konsumen dengan baik (Endah 2014). Pemasar perlu memahami perilaku konsumen dalam membeli kosmetik halal untuk menentukan strategi pemasaran yang terbaik.

Peningkatan permintaan kosmetik halal didorong oleh peningkatan pengetahuan dan informasi produk halal (Farlina et al. 2015). Jihan dan Musa (2014) menyatakan bahwa konsumen yang semakin religius maka konsumen tersebut akan mendapatkan lebih banyak pengetahuan dan informasi produk halal, sehingga hal ini bisa berdampak pada permintaan kosmetik halal. Pengetahuan akan produk halal terutama pada kosmetik halal (halal knowledge) juga merupakan salah satu hal yang dipertimbangkan konsumen dalam membeli kosmetik halal. Semakin baik pengetahuan akan kehalalan suatu produk maka akan berpengaruh pada perilaku pembelian konsumen, dimana konsumen akan lebih memilih kosmetik halal. Begitu juga dengan sikap konsumen yang dapat memengaruhi perilaku pembelian. Semakin positif sikap konsumen terhadap kosmetik halal, maka perilaku pembelian konsumen terhadap kosmetik halal juga akan semakin positif.

Penelitian tentang produk halal sering dijumpai penelitian pada industri makanan halal, padahal industri kosmetik halal juga sedang berkembang pesat. Penelitian pada perilaku konsumen industri halal lebih sering menguji model TRA ataupun TPB yang dikembangkan oleh Ajzen (1980), seperti penelitian yang dilakukan oleh Lada et al. (2009), Mukhtar dan Butt (2012), Endah (2014), dan Aisyah (2017).

Penelitian tentang perilaku konsumen yang menggunakan variabel pengetahuan produk halal dan tingkat religiusitas masih terbatas, sehingga penelitian ini akan menggunakan variabel pengetahuan produk halal (halal knowledge), religiusitas (religiosity), dan sikap (attitude) untuk menguji pengaruhnya terhadap perilaku (behavior) konsumen terhadap kosmetik halal di Surabaya. Responden dalam penelitian ini adalah muslimah generasi Y. Generasi Y merupakan generasi yang unik jika dibandingkan generasi sebelumnya. Generasi $\mathrm{Y}$ adalah generasi yang consumption oriented, generasi cerdas, trendsetter, dan sadar akan merk (Khalek dan Ismail 2015). Penelitian tentang perilaku konsumen terhadap kosmetik halal di Indonesia dari sudut pandang konsumen muslim generasi Y masih terbatas, sehingga hasil penelitian ini diharapkan mampu memberikan kontribusi ilmu baik bagi akademi maupun praktisi.

\section{Tinjauan Pustaka}

\subsection{Halal Knowledge}

Pengetahuan (knowledge) mengacu pada fakta, perasaan atau pengalaman yang dikenal oleh seseorang ataupun sekelompok orang. Knowledge berarti kesadaran atau keakraban (familiar) yang didapat melalui pengalaman ataupun pembelajaran. Knowledge dapat juga diartikan keahlian dan keterampilan yang didapat seseorang maupun sekelompok orang melalui pemahaman teoritis ataupun praktis dari suatu subjek tertentu (Che Ahmat et al., 2011; Sinclair, 2010, dalam Rahman et al., 2015). Simanjutak dan Dewantara (2014) menyatakan bahwa pengetahuan yang baik tentang produk halal dipengaruhi oleh pengalaman 
INOBIS: Jurnal Inovasi Bisnis dan Manajemen Indonesia

Volume 1, Nomor 3, Juni 2018

Elfira Maya Adiba; Dewi Ayu Wulandari

dan informasi tentang produk halal. Pengetahuan adalah hal yang penting bagi konsumen untuk memutuskan membeli suatu produk terutama produk yang halal (Maichum et al. 2017).

Konsumen yang lebih berpengetahuan akan berpengaruh pada perilakunya saat mengevaluasi atribut produk. Aertsens et al. (2011) menjelaskan bahwa kesadaran yang semakin meningkat dan pengetahuan (knowledge) akan produk makanan organik berpengaruh positif dan signifikan terhadap sikap dan level konsumsi makanan organik. Perilaku konsumen (consumer behavior) merupakan kesediaan konsumen untuk melakukan perilaku aktual terhadap produk halal (Al-Otoum dan Nimri 2015). Perilaku konsumen juga berarti perilaku dalam memilih produk mana yang hendak dibeli konsumen, yang mewakili preferensi konsumen tersebut untuk produk tertentu (Hassan et al. 2010). Perilaku konsumen dalam penelitian ini berarti preferensi konsumen dalam memilih kosmetik berlabel halal.

Konsumen yang lebih berpengetahuan tentang produk halal akan lebih berpotensi melakukan perilaku aktual seperti membeli langsung produk halal. Peningkatan permintaan kosmetik halal didorong oleh peningkatan pengetahuan dan informasi tentang produk halal (Farlina et al. 2015). Jihan dan Musa (2014) menyatakan bahwa konsumen yang semakin religius maka konsumen tersebut akan mendapatkan lebih banyak pengetahuan dan informasi produk halal, sehingga hal ini bisa berdampak pada permintaan kosmetik halal. Simanjutak dan Dewantara (2014) serta Ahmad et al. (2015) sebelumnya sudah melakukan penelitian untuk menguji hubungan antara pengetahuan tentang produk halal. Penelitian tentang pengaruh pengetahuan terhadap perilaku konsumen kosmetik halal masih terbatas, oleh karena itu hipotesis pertama dalam penelitian ini adalah:

H1: Halal Knowledge berpengaruh positif dan signifikan terhadap consumer behavior

\subsection{Islamic Religiosity}

Agama merupakan salah satu hal yang penting untuk mengambil keputusan karena agama merupakan fondasi yang menuntun seseorang untuk berperilaku sesuai hukum dan etika. Religiosity merupakan sejauh mana seorang individu berkomitmen pada agamanya yang tercermin pada sikap dan perilakunya (Ahmad et al. 2015).

Peneliti consumer behavior sebelumnya telah menemukan bahwa religiosity dapat memengaruhi sikap konsumen (attitude) dan perilaku (behavior). Hasil penilitian Ahmad et al. (2015) menunjukkan bahwa Islamic religiosity berpengaruh positif dan signifikan terhadap perilaku konsumen terhadap kosmetik halal. Konsumen yang semakin religius maka akan semakin melakukan pembelian nyata (aktual) terhadap kosmetik halal. Berdasarkan uraian tersebut, maka hipotesis kedua dalam penelitian ini yaitu:

H2: Islamic religiosity berpengaruh positif dan signifikan terhadap consumer behavior

\subsection{Attitude}

Sikap (attitude) menggambarkan hasil evaluasi seseorang terhadap suatu entitas (baik berupa objek maupun perbuatan), apakah dia suka atau tidak suka (Azjen, 1991, dalam Endah, 2014). Maichum et al. (2017) menejelaskan bahwa sikap terhadap makanan halal berarti evaluasi responden baik yang menguntungkan ataupun tidak untuk melakukan atau tidak melakukan suatu perilaku tertentu. Al-Otoum dan Nimri (2015) menjelaskan bahwa attitude merupakan perasaan positif atau negatif konsumen yang hasilnya terlihat pada sikap tertentu. Semakin positif sikap konsumen terhadap kosmetik halal, maka konsumen akan semakin melakukan pembelian aktual pada kosmetik halal. Simanjutak dan Dewantara (2014) dalam penelitiannya menunjukkan hasil bahwa sikap mahasiswa berpengaruh pada perilaku 
INOBIS: Jurnal Inovasi Bisnis dan Manajemen Indonesia

Volume 1, Nomor 3, Juni 2018

Elfira Maya Adiba; Dewi Ayu Wulandari

membaca label halal pada makanan. Berdasarkan uraian tersebut maka hipotesis ketiga dalam penelitian ini yaitu:

\section{H3: Attitude berpengaruh positif dan signifikan terhadap consumer behavior}

\subsection{Consumer Behavior}

Kotler (2004, dalam Shamser, 2016) mendefinisikan consumer behavior sebagai kombinasi mental, emosi, dan aktivitas fisik yang digunakan seseorang untuk memilih, membeli, menggunakan, maupun tidak menggunakan produk atau jasa yang memenuhi kebutuhan dan keinginan mereka. Consumer behavior juga berarti cerminan pengambilan keputusan konsumen dan aktivitas fisik yang dilakukan seseorang saat mengevaluasi, memeroleh, menggunakan atau tidaknya suatu barang dan jasa (Schiffman and Kanuk 2004:23, dalam Shamser 2016). Perilaku konsumen dalam konteks ini yaitu perilaku pembelian aktual atau nyata.

Berdasarkan uraian di atas mengenai hipotesis, maka kerangka konseptual penelitian ini yaitu:

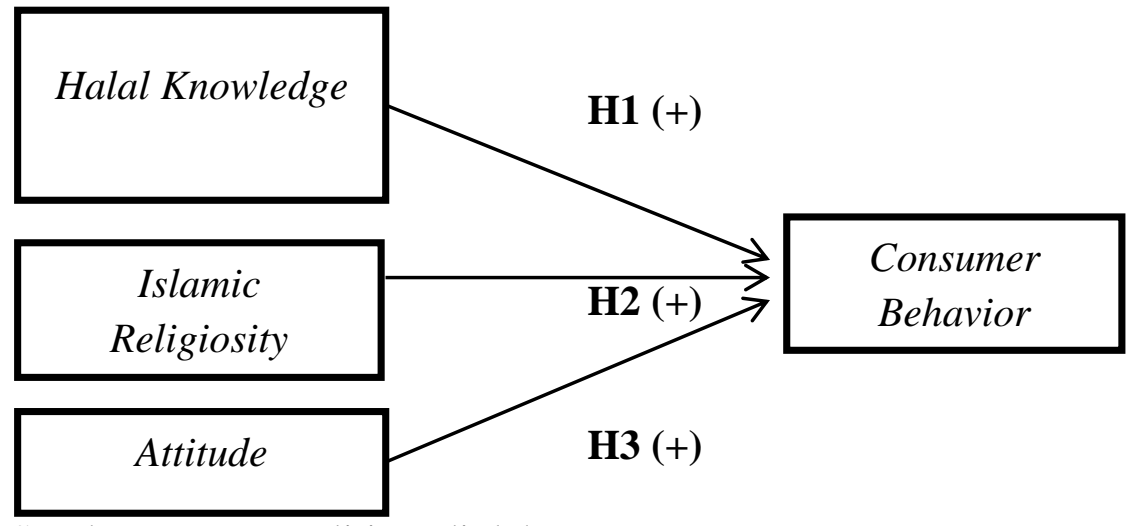

Sumber: Data Penelitian, diolah.

Gambar 1

Kerangka Konseptual

\section{Metode Penelitian}

Data dalam penelitian merupakan data primer yang didapat melalui penyebaran kuesioner. Penelitian ini menggunakan pendekatan kuantitatif yakni dengan mengadakan pengujian hipotesis, pengukuran data, dan penarikan simpulan. Penelitian ini memiliki tiga variabel bebas dan satu variabel terikat. Subjek penelitian adalah generasi Y karena generasi $\mathrm{Y}$ adalah generasi yang dinamis yang memiliki perhatian pada isu global dan sosial. Generasi $\mathrm{Y}$ adalah segmen konsumen yang besar dan kuat dengan a long future of potential consumer decisions (Srinivasan dan Sankar 2015).

Data penelitian terkumpul dari 101 responden, kemudian data dianalisis menggunakan regresi berganda atau Multiple Regression Analysis (MRA). Model regresi pada penelitian ini yaitu:

$Y=\beta_{0}+\beta_{1} X_{1}+\beta_{2} X_{2}+\beta_{3} X_{3}+e$

dimana:

$\mathrm{Y}=$ Consumer Behavior

$\mathrm{X}_{1} \quad=$ Halal Knowledge

$\mathrm{X}_{2} \quad=$ Islamic Religiosity 
INOBIS: Jurnal Inovasi Bisnis dan Manajemen Indonesia

Volume 1, Nomor 3, Juni 2018

Elfira Maya Adiba; Dewi Ayu Wulandari

Objek dalam penelitian ini yaitu pengetahuan tentang produk halal (halal knowledge), religiusitas Islami (Islamic religiosity), sikap (attitude), dan perilaku konsumen (consumer behavior). Definisi operasional masing-masing variabel dalam penelitian ini yaitu:

Tabel 1

Definisi Operasional Variabel

\begin{tabular}{|l|l|l|}
\hline No & \multicolumn{1}{|c|}{ Variabel } & \multicolumn{1}{c|}{ Definisi Operasional } \\
\hline 1. & Halal Knowledge & $\begin{array}{l}\text { Pemahaman respoden terhadap kehalalan kosmetik yang tidak } \\
\text { hanya dari bahan pembuatan, tetapi juga dari proses pembuatan } \\
\text { hingga pemasaran }\end{array}$ \\
\hline 2. & Islamic Religiosity & Tingkat religiusitas responden dalam kehidupan sehari-hari \\
\hline 3. & Attitude & Sikap responden dalam memilih produk kosmetik halal \\
\hline 4. & Consumer Behavior & Perilaku responden dalam memutuskan membeli kosmetik halal \\
\hline
\end{tabular}

Sumber: Data Penelitian, diolah

\section{Hasil dan Pembahasan}

\subsection{Uji Validitas dan Reliabilitas}

Uji validitas dilakukan untuk mengetahui kevalidan suatu kuesioner. Kuesioner dapat dikatakan valid jika pertanyaan pada kuesioner mampu mengungkapkan sesuatu yang akan diukur (Ghozali 2016:52). Jika korelasi antara item dengan total skor mempunyai nilai signifikansi $<0.05$ maka indikator tersebut valid untuk mengukur konstruk yang dimaksud. Uji validitas dalam penelitian ini menggunakan dua tahap. Tahap pertama adalah menguji validitas pada sampel kecil sejumlah 30 sampel. Hasil uji validitas pada sampel kecil menunjukkan bahwa seluruh item pertanyaan dalam kuesioner penelitian ini valid. Tahap kedua uji validitas dilakukan untuk seluruh sampel yang berjumlah 101. Tabel 2 menunjukkan hasil uji validitas untuk 101 sampel. Berdasarkan tabel tersebut terlihat bahwa masing-masing item pertanyaan dalam kuesioner penelitian ini adalah valid.

Uji reliabilitas dilakukan untuk menguji konsistensi alat ukur. Ghazali (2016:47) menjelaskan bahwa suatu kuesioner dikatakan reliabel atau handal jika jawaban responden terhadap pertanyaan adalah konsisten atau stabil dari waktu ke waktu. Uji reliabilitas pada penelitian ini juga dilakukan dengan dua tahap yaitu tahap pertama uji reliabilitas pada sampel kecil yang hasilnya adalah semua indikator dalam penelitian ini adalah reliabel. Tahap kedua adalah uji reliabilitas pada seluruh sampel. Tabel 3 menunjukkan ahsil uji reliabilitas pada seluruh sampel. Berdasarkan tabel 3 dapat dilihat bahwa cronbach's alpha semua variabel lebih dari 0,7. Menurut Ghozali (2016:48), pengujian statistik dikatakan reliabel untuk mengukur variabel jika memiliki nilai Cronbach's Alpha lebih dari 0,70. Hal ini dapat disimpulkan bahwa semua variabel dalam penelitian ini adalah reliabel. 
INOBIS: Jurnal Inovasi Bisnis dan Manajemen Indonesia Volume 1, Nomor 3, Juni 2018

Elfira Maya Adiba; Dewi Ayu Wulandari

Tabel 2

Hasil Uji Validitas

\begin{tabular}{|c|c|c|c|c|}
\hline \multirow[b]{2}{*}{ Variabel } & \multirow[b]{2}{*}{ Indikator } & \multicolumn{3}{|c|}{ Validitas } \\
\hline & & Korelasi & $\begin{array}{c}\text { Signifikan } \\
\text { si }\end{array}$ & $\begin{array}{c}\text { Keteranga } \\
n\end{array}$ \\
\hline \multirow{5}{*}{ 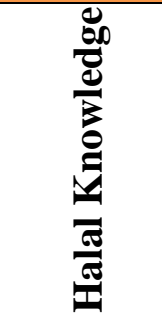 } & HK_1 & 0.776 & 0.000 & Valid \\
\hline & HK_2 & 0.751 & 0.000 & Valid \\
\hline & HK_3 & 0.628 & 0.000 & Valid \\
\hline & HK_4 & 0.758 & 0.000 & Valid \\
\hline & HK_5 & 0.758 & 0.000 & Valid \\
\hline \multirow{19}{*}{ 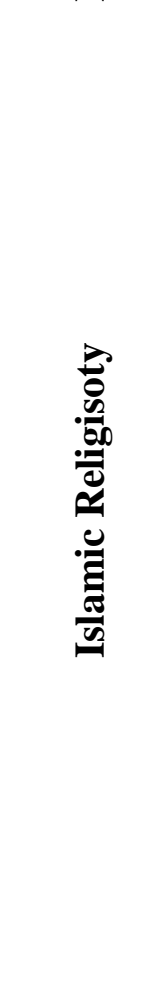 } & IR_1 & 0.661 & 0.000 & Valid \\
\hline & IR_2 & 0.678 & 0.000 & Valid \\
\hline & IR_3 & 0.683 & 0.000 & Valid \\
\hline & IR_4 & 0.508 & 0.000 & Valid \\
\hline & IR_5 & 0.622 & 0.000 & Valid \\
\hline & IR_6 & 0.743 & 0.000 & Valid \\
\hline & IR_7 & 0.756 & 0.000 & Valid \\
\hline & IR_8 & 0.512 & 0.000 & Valid \\
\hline & IR_9 & 0.690 & 0.000 & Valid \\
\hline & IR_10 & 0.579 & 0.000 & Valid \\
\hline & IR_11 & 0.739 & 0.000 & Valid \\
\hline & IR_12 & 0.739 & 0.000 & Valid \\
\hline & IR_13 & 0.520 & 0.000 & Valid \\
\hline & IR_14 & 0.426 & 0.000 & Valid \\
\hline & IR_15 & 0.483 & 0.000 & Valid \\
\hline & IR_16 & 0.581 & 0.000 & Valid \\
\hline & IR_17 & 0.631 & 0.000 & Valid \\
\hline & IR_18 & 0.598 & 0.000 & Valid \\
\hline & IR_19 & 0.591 & 0.000 & Valid \\
\hline \multirow{5}{*}{  } & $\mathrm{AT}_{-} 1$ & 0.926 & 0.000 & Valid \\
\hline & $\mathrm{AT}_{2} 2$ & 0.915 & 0.000 & Valid \\
\hline & $\mathrm{AT}_{-} 3$ & 0.857 & 0.000 & Valid \\
\hline & $\mathrm{AT}_{-} 4$ & 0.814 & 0.000 & Valid \\
\hline & AT_5 & 0.852 & 0.000 & Valid \\
\hline \multirow{4}{*}{ 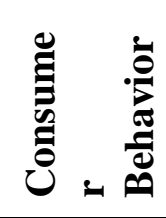 } & CB_1 & 0.926 & 0.000 & Valid \\
\hline & CB_2 & 0.952 & 0.000 & Valid \\
\hline & CB_3 & 0.927 & 0.000 & Valid \\
\hline & CB_4 & 0.900 & 0.000 & Valid \\
\hline
\end{tabular}

Sumber: Output SPSS, diolah 
INOBIS: Jurnal Inovasi Bisnis dan Manajemen Indonesia

Volume 1, Nomor 3, Juni 2018

Elfira Maya Adiba; Dewi Ayu Wulandari

Tabel 3

Hasil Uji Reliabilitas

\begin{tabular}{|l|c|c|}
\hline \multicolumn{1}{|c|}{ Variabel } & $\begin{array}{c}\text { Cronbach's } \\
\text { Alpha }\end{array}$ & Keterangan \\
\hline Halal Knowledge & 0,786 & Reliabel \\
\hline Islamic Religiosity & 0,905 & Reliabel \\
\hline Attitude & 0,922 & Reliabel \\
\hline Consumer Behavior & 0,938 & Reliabel \\
\hline
\end{tabular}

Sumber: output SPSS, diolah.

\subsection{Uji Normalitas dan Asumsi Klasik}

Uji normalitas dilakukan untuk mengetahui apakah dalam model regresi, variabel pengganggu atau residual memiliki distribusi normal (Ghozali 2016:154). Data dikatakan terdistribusi normal jika nilai signifikansi lebih dari 0,05. Data penelitian ini terdistribusi normal karena nilai signifikansinya 0,165. Tabel 4 berikut ini menunjukkan hasil uji normalitas dan asumsi klasik.

Tabel 4

Hasil Uji Normalitas dan Asumsi Klasik

\begin{tabular}{|l|l|l|}
\hline \multicolumn{1}{|c|}{ Uji Asumsi Klasik } & \multicolumn{1}{c|}{ Hasil Uji } & \multicolumn{1}{c|}{ Keputusan } \\
\hline Uji Normalitas & Sig: 0.165 & Data normal \\
\hline Uji Multikolinearitas & VIF (Halal Knowledge): & Tidak ada Gejala Multikolinearitas \\
& 2.271 & Tidak ada Gejala Multikolinearitas \\
& $\begin{array}{l}\text { VIF (Islamic religiosity): } \\
1.473\end{array}$ & Tidak ada Gejala Multikolinearitas \\
\hline & VIF (Attitude): 2.126 & Tidak ada Gejala Autokorelasi \\
\hline Uji Autokorelasi & Durbin-Watson: 1.898 & Tidak ada Gejala \\
Uji & Sig (Halal Knowledge): 0.417 & Tidak ada Gejala \\
Heteroskedastisitas & Heteroskedastisitas \\
\hline & Sig (Islamic religiosity): & Tidak ada Gejala \\
& 0.926 & Heteroskedastisitas \\
\hline & Sig (Attitude): 0.713 & \\
& &
\end{tabular}

Sumber: Output SPSS, diolah

Uji asumsi klasik yang pertama yaitu uji multikolinearitas. Uji multikolinearitas digunakan untuk mengetahui apakah dalam model regresi terdapat hubungan antar variabel bebas. Uji multikolinearitas dilihat dari nilai VIF. Nilai VIF > 10 menunjukkan terjadi gejala multikolinearitas (Ghozali 2016:103). Nilai VIF masing-masing variabel bebas dalam penelitian ini adalah kurang dari 10. Hal ini menunjukkan bahwa tidak ada gejala multikolinearitas.

Uji autokorelasi digunakan untuk apakah dalam model regresi ada korelasi antara kesalahan pengganggu pada periode $t$ dengan kesalahan pengganggu pada periode sebelumnya (t-1). Salah satu cara untuk menguji autokorelasi yaitu dengan menganalisis nilai Durbin-Watson (Ghozali 2016:107-108). Berdasarkan tabel diatas dapat dianalisis bahwa tidak ada gejala autokorelasi. Analisis uji autokorelasi dapat dilihat tabel berikut ini. 
INOBIS: Jurnal Inovasi Bisnis dan Manajemen Indonesia

Volume 1, Nomor 3, Juni 2018

Elfira Maya Adiba; Dewi Ayu Wulandari

Tabel 4

Analisis Uji Autokorelasi

\begin{tabular}{|c|c|c|}
\hline Uji Durbin-Watson & Analisis & Keputusan \\
\hline DW $($ Durbin-Watson $)=1,898$ & \multirow{3}{*}{$\begin{array}{l}\mathrm{DU}<\mathrm{D}<4-\mathrm{DU}= \\
1,7374<1,898<2,2626\end{array}$} & \multirow{3}{*}{$\begin{array}{l}\text { Tidak ada autokorelasi } \\
\text { positif atau negatif }\end{array}$} \\
\hline $\mathrm{DL}=1,6153$ & & \\
\hline $\mathrm{DU}=1,7374$ & & \\
\hline
\end{tabular}

Sumber: Output SPSS, diolah.

Uji heteroskedastisitas dilakukan untuk mengetahui apakah dalam model regresi terjadi ketidaksamaan variance dan residual antara satu pengamatan ke pengamatan yang lain. Uji yang dilakukan untuk mendeteksi gejala heteroskedastisitas yaitu uji Glejser (Ghozali 2016: 134). Hasil uji Glejser ini dapat dianalisis dari nilai signifikansi. Jika nilai signifikansi lebih dari 0,05 dapat dinyatakan tidak terdapat gejala heteroskedastisitas. Berdasarkan tabel diatas, nilai signifikansi variabel halal knowledge yaitu 0,417, variabel Islamic religiosity yaitu 0,962, dan variabel attitude sebesar 0,713. Nilai signifikansi masing-masing variabel bebas lebih dari 0,05 . Hal ini berarti tidak terjadi gejala heteroskedastisitas pada model regresi.

\subsection{Uji Regresi Linear Berganda}

Uji regresi linear berganda dilakukan untuk mengatahui pengaruh variabel bebas terhadap variabel terikat. Berikut adalah hasil analisis regresi linear berganda:

Tabel 5

Hasil Uji Regresi Berganda

\begin{tabular}{lcccl}
\hline Variabel & $\mathrm{B}$ & $\mathrm{t}$ hitung & Sig. & $\mathrm{r}^{2}$ \\
\hline Constant & -1.620 & - & 0.106 & - \\
Halal Knowledge (HK) & 0.064 & 1.049 & 0.297 & 0.011 \\
Islamic Religiosity (IR) & 0.028 & 1.533 & 0.129 & 0.023 \\
Attitude (AT) & 0.717 & 0.805 & 0.000 & 0.648 \\
Consumer Behavior (CB) & $\mathrm{F}_{\text {hitung }}=158,210 \quad$ Sig $=0,000$ & \\
& $\mathrm{R}^{2}=0,829$ & & \\
\hline
\end{tabular}

Sumber: Output SPSS, diolah.

Berdasarkan hasil uji regresi linear berganda, maka persamaan regresi adalah sebagai berikut:

$$
\mathrm{CB}=-1,620+0,064 \mathrm{HK}+0,028 \mathrm{IR}+0,717 \mathrm{AT}
$$

Koefisien-koefisien tersebut bermakna yaitu ketika halal knowledge semakin meningkat atau semakin baik maka consumer behavior terhadap kosmetik halal akan semakin positif atau semakin baik. Semakin religius (Islamic religiosity) konsumen kosmetik halal, maka consumer behavior terhadap kosmetik halal akan semakin positif atau semakin baik. Begitu juga dengan variabel sikap (attitude) yang semakin positif maka consumer behavior terhadap kosmetik halal juga akan semakin positif atau semakin baik. Hubungan antara variabel bebas dan terikat diatas adalah hubungan positif karena terlihat dari tanda positif pada masingmasing koefisien. 
INOBIS: Jurnal Inovasi Bisnis dan Manajemen Indonesia

Volume 1, Nomor 3, Juni 2018

Elfira Maya Adiba; Dewi Ayu Wulandari

Uji F dilakukan untuk mengetahui apakah variabel bebas secara simultan atau bersamasama berpengaruh terhadap variabel terikat, yaitu dengan menganalisis nilai signifikansi. Hasil uji $\mathrm{F}$ menunjukkan nilai signifikansi adalah 0,000 (Sig < 0,05) dan bertanda positif. Hasil uji ini menunjukkan bahwa variabel halal knowledge, Islamic religiosity, dan attitude secara simultan berpengaruh positif dan signifikan terhadap consumer behavior.

Koefisien determinasi $\left(\mathrm{R}^{2}\right)$ menunjukkan seberapa besar kontribusi seluruh variabel bebas secara simultan dalam memengaruhi variabel terikat. Berdasarkan tabel diatas nilai $\mathrm{R}^{2}$ adalah 0,829. Artinya adalah seluruh variabel bebas secara simultan memengaruhi consumer behavior sebesar $82,9 \%$, sisanya dipengaruhi oleh variabel lain di luar model. Semakin tinggi nilai $\mathrm{R}^{2}$ maka semakin bagus atau kontribusi seluruh variabel bebas dalam menjelaskan variabel terikat semakin tinggi.

Uji t dilakukan untuk mengetahui pengaruh variabel bebas atau independen secara parsial atau terpisah. Nilai signifikansi variabel halal knowledge pada uji t diatas adalah 0,297 (Sig > 0,05). Hasil ini menunjukkan bahwa variabel halal knowledge secara parsial tidak memengaruhi consumer behavior. Nilai signifikansi variabel Islamic religiosity pada uji t ini adalah 0,129 (Sig > 0,05). Hasil ini menunjukkan bahwa variabel halal knowledge secara parsial tidak memengaruhi consumer behavior. Nilai signifikansi variabel attitude pada uji $\mathrm{t}$ ini adalah 0,00 (Sig < 0,05). Hasil ini menunjukkan bahwa variabel attitude secara parsial berpengaruh positif dan signifikan terhadap consumer behavior.

Berdasarkan tabel diatas juga dapat dilihat koefisien determinasi parsial $\left(\mathrm{r}^{2}\right)$ variabel halal knowledge 0,105 atau 0,011. Hal ini berarti kontribusi halal knowledge dalam memengaruhi consumer behavior sebesar 1,1\%. Koefisien determinasi parsial variabel Islamic religiosity sebesar 0,153 atau 0,023 , artinya adalah kontribusi Islamic religiosity dalam memengaruhi consumer behavior sebesar 2,3\%. Koefisien determinasi parsial variabel attitude sebesar 0,805 atau 0,648. Hal ini berarti kontribusi attitude dalam memengaruhi consumer behavior sebesar $64,8 \%$. Variabel bebas yang paling dominan dalam memengaruhi consumer behavior yaitu variabel attitude, yang terlihat dari koefisien determinasi parsialnya yang paling tinggi yaitu sebesar $64,8 \%$.

\subsection{Pembahasan}

Hasil penelitian menunjukkan bahwa variabel halal knowledge tidak memiliki pengaruh signifikan terhadap behavior konsumen muslim generasi Y di Surabaya dalam pembelian produk kosmetik halal. Hal ini dilihat dari nilai signifikansi 0,297 atau lebih dari 0,05. Hasil penelitian ini sejalan dengan penelitian sebelumnya yang dilakukan oleh Ahmad et al. (2015). Konsumen yang memiliki pengetahuan ataupun informasi tentang produk kosmetik halal seharusnya lebih sadar tentang pentingnya kehalalan kosmetik yang dibeli, akibatnya konsumen akan lebih memilih produk kosmetik halal. Responden dalam penelitian ini yang merupakan generasi Y tidak mempertimbangkan aspek halal terhadap kosmetik yang dibeli. Konsumen generasi Y seharusnya lebih mempertimbangkan pengetahuan tentang kehalalan suatu produk termasuk dalam pembelian kosmetik. Generasi Y tumbuh pada era digital yang selalu terhubung dengan internet, sehingga informasi bagi generasi $\mathrm{Y}$ adalah hal yang cenderung mudah dan cepat didapatkan. Hal tersebut dapat memengaruhi cara mereka mencari informasi, memecahkan masalah, dan tentunya berpengaruh pada perilaku pembelian (Widhyanto 2016).

Konsumen generasi $\mathrm{Y}$ dalam mendapatkan informasi mengenai kosmetik, dapat mengakses internet dengan membaca ulasan dari blog, instagram, youtube channel beauty blogger (influencer), ataupun media sosial lainnya. Seorang beauty blogger mengulas produk 
INOBIS: Jurnal Inovasi Bisnis dan Manajemen Indonesia

Volume 1, Nomor 3, Juni 2018

Elfira Maya Adiba; Dewi Ayu Wulandari

kosmetik apa saja yang mereka gunakan ataupun dari iklan (endorsement) melalui akun media sosialnya yang dapat diakses semua kalangan, terutama generasi Y. Beauty blogger yang memiliki beratus ribu juta pengikut pada akun media sosialnya, dimana suatu produk kosmetik yang sudah diulas, dapat memengaruhi permintaan akan produk kosmetik tersebut. Tidak semua beauty blogger memperhatikan kehalalan kosmetik yang mereka pakai ataupun yang mereka ulas. Tidak hanya ulasan dari beauty blogger, generasi Y juga akan mengakses internet untuk membaca testimonial atau ulasan dari pengguna kosmetik yang sudah menggunakan suatu produk kosmetik tertentu. Hal ini juga memengaruhi pembelian kosmetik para pengikut atau penonton yang merupakan konsumen generasi Y. Pencarian informasi yang dilakukan oleh generasi $\mathrm{Y}$ tersebut dikarenakan mereka akan membeli produk yang benar-benar mereka yakini. Ordun (2015) dalam penelitiannya juga menyatakan bahwa generasi $\mathrm{Y}$ adalah generasi yang sangat aktif di media sosial, sehingga keputusan pembelian konsumen generasi Y lebih dipengaruhi oleh pendapat orang lain yang dapat mereka baca di internet.

Kosmetik luar negeri yang semakin marak beredar di Indonesia juga membuat generasi Y di Surabaya untuk tidak ketinggalan untuk memakainya. Permintaan kosmetik dari luar negeri, misalnya kosmetik dari Korea Selatan juga semakin meningkat, terlihat dari beberapa situs e-commerce yang sering mengalami kehabisan produk kosmetik dari negera tersebut. Hal ini juga dipengaruhi oleh ulasan dari beauty blogger, iklan selebriti, dan tayangan seperti film atau drama dimana para aktor atau aktrisnya sedang menggunakan produk tersebut dalam beberapa adegan. Berkembangnya kosmetik dari luar negeri juga terlihat dari pertumbuhan jumlah outlet yang tidak hanya di ibukota, tetapi juga sudah merambah di kota-kota besar di Indonesia. Beberapa kosmetik dari luar negeri tersebut belum mendapat sertifikasi halal dari MUI. Iklan kosmetik yang tidak berlabel halal yang begitu pesat juga membuat halal knowledge tidak menjadi pertimbangan lagi bagi generasi Y dalam pembelian kosmetik. Berdasarkan penelitian yang dilakukan oleh Angela dan Effendy (2015), alasan generasi Y dalam membeli smartphone termasuk dalam faktor sosial yaitu alasan untuk mengikuti tren atau perkembangan zaman. Begitu juga dengan kosmetik yang merupakan sesuatu yang harus dimiliki oleh muslim generasi Y karena tidak mau tertinggal dengan perkembangan zaman yang serba cepat dan mudah ini.

Variabel Islamic religiosity juga tidak berpengaruh positif dan signifikan terhadap consumer behavior dalam pembelian kosmetik halal. Hasil penelitian ini tidak sejalan dengan penelitian yang dilakukan Ahmad et al. (2015). Konsumen yang semakin religius seharusnya akan semakin memperhatikan kehalalan suatu produk termasuk kosmetik, namun dalam penelitian ini religiusitas konsumen generasi Y di Surabaya bukan menjadi pendorong dalam pembelian kosmetik. Hal ini disebabkan adanya kecenderungan generasi Y menggunakan merk tertentu untuk mempertahankan dan menguatkan jati diri mereka, sehingga religiusitas tidak menjadi alasan mereka dalam pembelian kosmetik. Sama seperti alasan sebelumnya bahwa generasi $\mathrm{Y}$ merupakan generasi yang reaktif dan sangat tanggap dengan informasi dari internet, sehingga apa yang mereka lihat dan dijadikan panutan adalah orang-orang yang mengisi konten media sosial di dunia maya. Hal ini menyebabkan perilaku dalam pembelian barang tidak didominasi oleh tingkat religiusitas.

Responden dalam penelitian ini merupakan wanita generasi Y. Ada beberapa faktor yang menentukan kebiasaan atau behavior dalam pembelian oleh seorang wanita yaitu adanya pengaruh dari keluarga atau orang terdekat lainnya misalnya teman atau rekan kerja. Keluarga atau orang terdekat lainnya cenderung memberikan pendapat mereka atau mereferensikan suatu produk tertentu, sehingga orang disekitarnya juga akan terpengaruh untuk membeli produk yang sama. Apalagi hubungan dalam keluarga misalnya ibu atau saudara perempuan, 
INOBIS: Jurnal Inovasi Bisnis dan Manajemen Indonesia

Volume 1, Nomor 3, Juni 2018

Elfira Maya Adiba; Dewi Ayu Wulandari

dimana produk tertentu cenderung sudah dipakai dalam jangka waktu yang lama. Hal inilah yang menyebabkan variabel halal knowledge dan Islamic religisity tidak berpengaruh pada consumer behavior pembelian kosmetik halal.

Seperti yang telah dijelaskan diatas bahwa ada pengaruh hal lain selain halal knowledge dan Islamic religisity terhadap consumer behavior, yaitu adanya pengaruh dari faktor sosial seperti pengaruh dari keluarga, teman, lingkaran kerja atau kuliah, gaya hidup komunitas, dan lainnya. Hal ini juga sudah dibuktikan oleh penelitian yang dilakukan Angela dan Effendi (2015) bahwa faktor-faktor brand loyalty smartphone pada generasi Y diantaranya adalah faktor internal dan eksternal. Faktor internal mencakup faktor-faktor psikologis yang melibatkan motivasi, persepsi, proses belajar, dan faktor-faktor pribadi yang melibatkan kepribadian dan nilai. Faktor-faktor eksternal mencakup faktor-faktor sosial yang melibatkan gaya hidup komunitas, lingkaran kerja atau kuliah, teman, lingkaran keluarga, dan media. Generasi Y yang tumbuh di era internet ini tidak lagi menjadikan pengetahuan akan kehalalan suatu produk dan religiusitas dalam perilaku pembelian kosmetik mereka.

Konsumen generai Y tidak hanya sekedar memilih dan membeli sebuah produk, namun mereka mempertimbangkan produk yang dapat menunjukkan siapa mereka (define who they are). Produk tersebut dapat menunjukkan kepribadian dan citra diri generasi Y. Ordun (2015) menjelaskan bahwa keputusan pembelian generasi $\mathrm{Y}$ sangat dipengaruhi oleh social influencer dari internet. Hal ini berbeda dengan generasi baby boomers yang mempertimbangkan pendapat seorang yang ahli dalam bidangnya dan pendapat teman dekat dalam memutuskan pembelian suatu produk. Ordun (2015) juga menjelaskan lebih jauh bahwa generasi Y menganggap label suatu produk merupakan sesuatu yang menggambarkan kepribadian mereka, menunjukkan jati diri mereka secara sosial, dan label tersebut menunjukkan kualitas. Generasi baby boomers dalam hal ini menganggap label juga menunjukkan kualitas suatu produk.

Variabel yang berpengaruh secara parsial terhadap customer behavior adalah attitude. Hal ini sejalan dengan penelitian yang dilakukan oleh Simanjutak dan Dewantara (2014). Semakin positif sikap konsumen terhadap kosmetik halal, maka konsumen akan semakin memilih kosmetik halal yang tercermin pada pembelian aktual. Perusahaan kosmetik halal perlu menjaga konsumen yang sudah memiliki sikap positif karena konsumen ini berpotensi menjadi konsumen yang loyal. Konsumen yang loyal bisa memengaruhi lingkungan sosialnya untuk ikut menggunakan kosmetik halal dan hal ini merupakan suatu bentuk pemasaran gratis yaitu melalui word of mouth (WOM).

\section{Simpulan}

Hasil uji regresi secara simultan adalah variabel halal knowledge, Islamic religiosity, dan attitude secara simultan berpengaruh signifikan terhadap behavior konsumen muslim generasi Y pengguna kosmetik halal di Surabaya. Hasil uji t pada model regresi adalah variabel halal knowledge dan Islamic religiosity tidak berpengaruh signifikan terhadap behavior. Variabel attitude merupakan variabel yang berpengaruh signifikan terhadap behavior konsumen muslim generasi Y pengguna kosmetik halal di Surabaya.

Variabel halal knowledge dan Islamic religiosity tidak berpengaruh signifikan terhadap consumer behavior. Pihak perusahaan kosmetik bekerja sama dengan MUI (Majelis Ulama Indonesia) selaku pemberi sertifikasi halal di Indonesia, perlu memberikan edukasi kepada konsumen generasi Y bahwa konsumen perlu memerhatikan kehalalan kosmetik, tidak hanya kehalalalan makanan dan minuman. Edukasi kepada generasi Y memerlukan iklan yang menarik melalui media sosial. Perusahaan kosmetik bisa mempromosikan produk halal 
INOBIS: Jurnal Inovasi Bisnis dan Manajemen Indonesia

Volume 1, Nomor 3, Juni 2018

Elfira Maya Adiba; Dewi Ayu Wulandari

melalui beauty blogger atupun pihak yang berpengaruh lainnya (social influencer) untuk mengkampanyekan pentingnya kehalalan produk kosmetik. Hal ini perlu dilakukan mengingat generasi Y akan mencari informasi suatu produk sebelum membelinya melalui internet. Generasi Y juga mempertimbangkan ulasan konsumen lain yang sudah menggunakan produk kosmetik yang menjadi target penggunaan, oleh karena itu perusahaan kosmetik perlu menjaga kualitas dan kepuasan konsumen.

Generasi Y yang merupakan generasi melek teknologi informasi yang dapat mengakses informasi secara cepat hendaknya tetap berpegang pada pengetahuan mereka akan kehalalan suatu produk kosmetik. Tidak hanya melihat ulasan dari para social influencer. Penelitian ini memiliki keterbatasan yaitu pengambilan data hanya di satu wilayah yaitu Surabaya. Penelitian selanjutnya dapat menggunakan responden dari beberapa wilayah di Jawa Timur, sehingga dapat dibandingkan hasilnya. Penelitian selanjutnya juga dapat menambahkan responden dari generasi yang berbeda, yaitu generasi $\mathrm{X}$ ataupun generasi $\mathrm{Z}$ sehingga dapat dibedakan consumer behavior antar generasi.

\section{Daftar Referensi}

Ahmad, A. N., Azmawani A. R., dan Suhaimi A. R. 2015. Assessing Knowledge and Religiosity on Consumer Behavior towards Halal Food and Cosmetic Products. International Journal of Social Science and Humanity 5/1.

Aisyah, M. 2017. Consumers Demand on Halal Cosmetics and Personal Care Products in Indonesia. Jurnal Ilmu Ekonomi Syariah (Journal of Islamic Economics) 9/1: 125-142.

Al-Otoum, F. J. dan Rawan. S. N. 2015. Antecedents of Consumers' Behavior towards Halal Food among Jordanian Customers: A Structural Equation Modeling (SEM) Approach. Journal of Marketing and Consumer Research 12.

Angela, T. dan Nurlaila E. 2015. Faktor-Faktor Brand Loyalty Smartphone pada Generasi Y. Jurnal Experientia 3/1.

Elasrag, H. 2016. Halal Industry: Key Challenges and Opportunities. Available at SSRN: https://ssrn.com/abstract=2735417.

Endah, N. H. 2014. Perilaku Pembelian Kosmetik Berlabel Halal oleh Konsumen Indonesia. Jurnal Ekonomi dan Pembangunan 22/1.

Farlina, Norafni, Zurina S., and Syahidawati S. 2015. Awareness and Perception of Muslim Consumers on Halal Cosmetics and Personal Care Products. International Journal of Business, Economics and Management 2/1: 1-14.

Ghozali, Imam. 2016. Aplikasi Analisis Multivariete dengan Program IBM SPSS 23. Semarang: Badan Penerbit Universitas Diponegoro.

Hassan, Y., Nik M. N. M., dan Hatinah A. B. 2010. Influence Of Shopping Orientation And Store Image On Patronage Of Furniture Store. International Journal of Marketing Studies 2/1: 175-184.

Jihan, A. dan Rosidah M. 2014. Factors Influencing Attitude towards Halal Cosmetic among Yound Adult Urban Muslim Women: A Focus Group Analysis. Elsevier ProcediaSocial and Behavioral Sciences 130: 129-134.

Khalek, A. A. dan Sharifah H. S. I. 2015. Why Are We Eating Halal - Using the Theory of Planned Behavior in Predicting Halal Food Consumption among Generation $\mathrm{Y}$ in Malaysia. International Journal of Social Science and Humanity 5/7.

Lada, S., Tanakinjal G. H. dan Amin, H. 2009. Predicting Intention to Choose Halal Products Using Theory of Reasoned Action. International Journal of Islamic and Middle Eastern Finance and Management 2/1: 66-76. 
INOBIS: Jurnal Inovasi Bisnis dan Manajemen Indonesia

Volume 1, Nomor 3, Juni 2018

Elfira Maya Adiba; Dewi Ayu Wulandari

Maichum, K., Surakiat P. dan Ke-Chung P. 2017. The Influence of Attitude, Knowledge and Quality on Purchase Intention towards Halal Food: A Case Study of Young NonMuslim Consumers in Thailand. International Journal of Management \& Social Sciences 6/03: 354-364.

Mohezar, S., Suhaiza Z., dan Zainorfarah Z. 2016. Halal Cosmetics Adoption Among Young Muslim Consumers in Malaysia: Religiosity Concern. GJAT 6/1.

Mukhtar, A. dan Muhammad M. B. 2012. Intention to Choose Halal Products: the Role of Religiosity. Journal of Islamic Marketing 3/2: 108-120.

Ordun, G. 2015. Millennial (Gen Y) Consumer Behavior, Their Shopping Preferences and Perceptual Maps Associated With Brand Loyalty. Canadian Social Science, 11/4: 40-55.

Rahman, A. A., Ebrahim A., dan Suhaimi A. R. 2015. Consumers and Halal Cosmetic Products: Knowledge, Religiosity, Attitude and Intention. Journal of Islamic Marketing $6 / 1$.

Simanjuntak, M. dan Dewantara M. M. 2014. The Effects of Knowledge, Religiosity Value, and Attitude on Halal Label Reading Behavior of Undergraduate Students. ASEAN Marketing Journal VI/2.

Srinivasan, R. dan Mahalakshmi S. 2015. Cause Related Marketing and Store loyalty of Youngsters. Journal of Business and Management 17/9: 29-35.

Swidi, A., Cheng W., Mohamad G. H., Asma A., dan Abdul W. M. K. 2010. The Mainstream Cosmetics Industry in Malaysia and The Emergence, Growth, and Prospects of Halal Cosmetics. In: The Third International Conference on International Studies (ICIS), $1^{\text {st }}$ $2^{\text {nd }}$ December 2010, Hotel Istana Kuala Lumpur. College of Law, Government and International Studies, Universiti Utara Malaysia, Sintok, pp. 1-20. ISBN 9789832078456.

Widhyanto, D. G. 2016. Studi Tipe Perilaku Pembelian Impulsif pada Konsumen Generasi Y. Jurnal Universitas Atma Jaya Yogyakarta $\underline{\text { http://e- }}$ journal.uajy.ac.id/10398/1/JURNALEM19560.pdf. pp. 1-15, diakses pada 2 Maret 2018. 